\title{
Application of Different Organic Wastes for Electricity Generation by Means of Double Chambered Microbial Fuel Cell Technology
}

\author{
Okeke Ugochukwu Chibueze*, Mbachu Ifeoma Adaora Chima \\ Department of Microbiology, Chukwuemeka Odumegwu Ojukwu University, Uli, Nigeria \\ Email address: \\ okekeugochukwu1@yahoo.com (O.U. Chibueze),2ifyadambachu@gmail.com (M. I. A. Chima) \\ * Corresponding author
}

\section{To cite this article:}

Okeke Ugochukwu Chibueze, Mbachu Ifeoma Adaora Chima. Application of Different Organic Wastes for Electricity Generation by Means of Double Chambered Microbial Fuel Cell Technology. Frontiers in Environmental Microbiology. Vol. 4, No. 4, 2018, pp. $94-102$. doi: $10.11648 /$ j.fem.20180404.11

Received: May 29, 2018; Accepted: July 2, 2018; Published: July 30, 2018

\begin{abstract}
Wastes generated by both agrobased industries and domestic units have high nutrient contents to support microbial growth but in Nigeria, these wastes are indiscriminately dumped and constitutes environmental and health hazards. Some of these wastes can be used to grow some bacterial species in microbial fuel cell to generate bioelectricity. The waste materials used in this work are, banana, and pineapple peels. Glucose was used for comparison. Bacterial species used were isolated from fluids collected from dustbins and soil, all within Chukwuemeka Odumegwu Ojukwu University, Uli campus. Microscopic characterization of the isolates by Grams reaction revealed the isolate to be Gram negative and Spore test were negative. Biochemical tests showed that the isolate were catalase positive, oxidase negative and citrate positive. By Bergys criteria, the isolate was shown to be Pseudomonas species. Genetic characterization confirmed the species to be Pseudomonas aeruginosa. Four (4) MFC's were fabricated with a liter transparent plastic for the anode and cathode poles. The electrodes used was graphite for the production of graphite-graphite fuel cells. A 3.75\% Sodium chloride, $2.2 \%$ agar salt bridge connected the chambers. Glucose, banana and pineapple peels were used as organic substrates and pure cultures of Pseudomonas aeruginosa were biocatalyst for the fuel cells. Result for effect of aeration with Pseudomonas aeruginosa by multimetric monitoring gave maximum power of $3.983 \times 10^{-4} \mathrm{~W}, 7.1625 \times 10^{-4} \mathrm{~W}$ and $8.9920 \times 10^{-4} \mathrm{~W}$ for glucose, banana peel and pineapple peel respectively, while non-aeration was $3.936 \times 10^{-4} \mathrm{~W}, 7.059 \times 10^{-4} \mathrm{~W}$ and $8.909 \times 10^{-4} \mathrm{~W}$ for glucose, banana peel and pineapple peel. Population growth determination by spectrophotometric method at wavelength $540 \mathrm{~nm}$ gave these results $1.148,1.572,1.714$ and 1.837 with Pseudomonas aeruginosa on days 1, 4, 7 and 10 respectively.
\end{abstract}

Keywords: Banana Peel, Multimetric Monitoring, Pineapple Peel, Population Growth Determination, Pseudomonas Aeruginosa, Spectrophotometric Method

\section{Introduction}

Most bacteria, in the process of metabolizing organic carbon sources, release electrons and protons. This is irrespective of the growth and incubation conditions prevalent. These electrons and protons may be harnessed by means of appropriate technologies for the production of bioelectricity. The development of microbial fuel cell is a right vision towards the actualization of this idea. There is indeed the need to pursue this technology as the dependence on fossil fuels has caused more release of greenhouse gases into the atmosphere, leading to global environmental pollution which is the major cause of global warming [36].

Potter [33] was the first to demonstrate that electrical current can be generated from degradation of organic compounds by bacteria or yeast [33]. Two decades later, Cohen [7] confirmed Potter's results and produced an overall voltage of $35 \mathrm{~V}$ at a current of $0.2 \mathrm{~mA}$ using a stacked bacterial fuel cell. These publications are generally considered the first reported cases of MFCs, but they didn't 
generate much interest since the current density and power output were very small [5].

Microbial fuel cells (MFCs) are devices that use bacteria as the catalysts to oxidize organic and inorganic matter to generate current [23]. Electrons produced by the bacteria from these substrates are transferred to the anode (negative terminal) and flow to the cathode (positive terminal) linked by a conductive material containing a resistor, or operated under a load (i.e., producing electricity that runs a device). By convention, a positive current flow from the positive to the negative terminal, a direction opposite to that of electron flow. In most MFCs the electrons that reach the cathode combine with protons that diffuse from the anode through a separator and oxygen provided from air; the resulting product is water [23].

In this study, the results of which are reported within, factors that influenced generation of electric current in a fabricated MFC that used Glucose, banana peel and pineapple peel as the substrate was investigated and the most efficient combination of values for the key factors were determined. The fabricated MFCs of the system allows for air at the cathode part to enhance degradation of the solid waste while the anode part is anaerobic to maximize generation of current.

It is the first-time banana peel and pineapple peel, were used respectively as substrates for MFC although cow manure was used in another research [42]. The population growth was determined using spectrophotometric method and the microbial community in the anode part of the MFCs was characterized biochemically and genetically, the effects of key parameters like aeration and non-aeration were also analyzed.

The aim of this work is to find out how effective the substrates under study can be on the organisms of choice for the production of electricity by microbial fuel cell technology

\section{Materials and Methods}

\subsection{Sample Collection}

Water samples were collected from dustbins from student's lodges at Chukwuemeka Odumegwu Ojukwu Universities, Uli campus. Using well labelled sterile sample bottles and transported to the laboratory within 30 minutes of collection. It was transported to the microbiology laboratory of the school were a tenfold serial dilution was carried out using sterilized test tubes and ready for further analysis.

\subsection{Sources of Organic Wastes}

In this research, two (2) substrates (organic wastes) were used for this research and they were obtained from domestic units. They include the following: Banana peel and pineapple peel. Industrial glucose were purchased and it served as a positive control.

\subsection{Preparation of Substrates (Wastes)}

The substrates (Glucose, banana peel, and pineapple peel) were collected aseptically using both sterile containers and sterile nylon bags respectively. They were dried and grounded, then $20 \mathrm{~g}$ of each was measured using a digital weighing balance and placed into a well labeled1000 ml conical flasks containing $500 \mathrm{ml}$ of distilled water respectively. Each was sterilized at $121^{\circ} \mathrm{C}$ and 15 PSI for 15 minutes. Phosphate buffer was also dissolved with $500 \mathrm{ml}$ of distilled water and was mixed with the sterilized substrates respectively, then refrigerated at $4^{\circ} \mathrm{C}$ for future use in the experiment.

\subsection{Isolation Test Bioelectrogenic Organism}

Test tube $10^{-2}$ of the serially diluted sample $(0.1 \mathrm{ml})$ was collected using a sterile syringe and inoculated onto already prepared centrimide agar plates aseptically prepared using the manufacturer's instructions by spread plating method using sterile hockey stick. The petri-plates were labelled appropriately and incubated invertedly at $37^{\circ} \mathrm{C}$ for 24 hours for visual evidence of growth. After 24hours incubation, the colonies were sub-cultured and re-subcultured on nutrient agar plates by striking method to obtain pure cultures of Pseudomonas aeruginosa. After visual evidence of growth, the pure cultures were stored at $4^{\circ} \mathrm{C}$ to be used for identification and to serve as a bioelectrogenic organism for the microbial fuel cell.

\subsection{Identification of Test Bioelectrogenic Organism}

The identification of the bioelectrogenic organism was based on morphological characteristics, biochemical tests and genetic identification. The morphological characteristics observed for the bacterial isolate after $24 \mathrm{~h}$ of growth included colonial appearance; shape, elevation, edge, optical characteristics, consistency, colony surface and pigmentation. Biochemical characterizations were done according to the method of Fawole and Oso [12]. Some of the key tests for identification included the following:

\subsubsection{Gram Staining Techniques}

A thin smear of each of the pure $24 \mathrm{~h}$ old culture was prepared on clean grease-free slides, fixed by passing over gentle flame. Each heat-fixed smear was stained by addition of 2 drops of crystal violet solution for $60 \mathrm{sec}$ and rinsed with water. The smear was again flooded with Lugol's iodine for $30 \mathrm{sec}$ and rinsed with water, decolourized with $70 \%$ alcohol for $15 \mathrm{sec}$ and were rinsed with distilled water. They were then counter stained with 2 drops of Safranin for $60 \mathrm{sec}$ and finally rinsed with water, then allowed to air dry. The smears were mounted on a microscope and observed under oil immersion objective lens. Gram negative cells appeared pink or red while gram positive organisms appeared purple (Fawole and Oso [12]).

\subsubsection{Spore Staining Technique}

This test is to detect the presence of bacteria endospores. Heat-fixed smears of the organisms were prepared on separate slides and flooded with 5\% Malachite green solution and steamed for a minute. The stain was washed off with water and counter stained with 2 drops of Safranin solutions 
for $20 \mathrm{sec}$. The slides were allowed to air dry and examined under oil immersion objective (X100) lens. Endospores stained green while vegetative cells stained pink (Cheesbrough [6]).

\subsubsection{Motility Test}

A sterile needle was used to pick a loop of a $24 \mathrm{~h}$ old culture and was stabbed onto triple sugar iron agar (TSI) in glass test tubes. The test tubes were incubated at $37^{\circ} \mathrm{C}$ for $24-$ 48 h. Non-motile bacteria had growth confined to the stab line with definite margins without spreading to surroundings area while motile bacteria gave diffused growth extending from the surface (modified Olutiola et al., [29]).

\subsubsection{Catalase Test}

A small quantity of the $24 \mathrm{~h}$ old cultures were transferred into a drop of $3 \%$ Hydrogen peroxide solution on a clean slide with the aid of sterile inoculating loop. Gas seen as white froth indicates the presence of catalase enzyme (Cheesbrough [6]).

\subsubsection{Methyl Red Test}

Five millimeters of glucose phosphate broth ( $1 \mathrm{~g}$ glucose, $0.5 \% \mathrm{KH} 2 \mathrm{PO} 4,0.5 \%$ peptone and $100 \mathrm{~mL}$ distilled water) were dispensed in clean test tubes and sterilized. The tubes were then inoculated with the test organisms and incubated at $37^{\circ} \mathrm{C}$ for $48 \mathrm{~h}$. At the end of incubation, few drops of methyl red solution were added to each test and colour change was observed. A red colour indicates a positive reaction (Olutiola et al., [29]).

\subsubsection{Voges-Proskaeur Test}

Five millimeter of glucose phosphate broth (1 g glucose, $0.5 \% \mathrm{KH} 2 \mathrm{PO} 4,0.5 \%$ peptone and $100 \mathrm{~mL}$ distilled water) were dispensed in clean test tubes and sterilized. The tubes were then inoculated with the test organisms and incubated at $37^{\circ} \mathrm{C}$ for $48 \mathrm{~h}$. After incubation, $6 \% \alpha$-naphtol and $6 \%$ Sodium hydroxide were added to about $1 \mathrm{~mL}$ of the broth culture. A strong red colouration formed within $30 \mathrm{~min}$ indicates positive reaction (Olutiola et al., [29]).

\subsubsection{Indole Test}

Tryptone broth $(5 \mathrm{~mL})$ was placed into different test tubes after which a loopful of the bacterial isolates was inoculated into the test tubes, leaving one of the test tubes uninoculated to serve as control. The test tubes were then incubated at $37^{\circ} \mathrm{C}$ for $48 \mathrm{~h}$. After incubation, $0.5 \mathrm{~mL}$ of Kovac's reagent was added and shaken gently; it was allowed to stand for 20 min to permit the reagent to rise. A red or red-violet color at the top surface of the tube indicates a positive result while yellow coloration indicates a negative result (Cheesbrough [6]).

\subsubsection{Citrate Test}

This test detects the ability of an organism to use citrate as a sole source of carbon and energy. About $2.4 \mathrm{~g}$ of citrate agar was dissolve in $100 \mathrm{~mL}$ of distilled water. About ten milliliter $(10 \mathrm{~mL})$ of citrate medium was dispensed into each tubes and covered, then sterilized and allowed to cool in a slanted position. The tubes were inoculated by streaking the organisms once across the surface. A change from green to blue indicates utilization of the citrate (Cheesbrough [6]).

\subsubsection{Oxidase Test}

A piece of filter paper was soaked with few drops of oxidase reagent. Sterile inoculating loop was used to pick a colony of the test organism and smeared on the filter paper. If the organism is oxidase producing, the phenylenediamine in the reagent will be oxidized to a deep purple color (Cheesbrough [6]).

\subsubsection{Sugar Fermentation}

Sugar fermentation test was carried out to determine the ability of organisms to ferment sugars with production of acid and gas. Triple sugar iron agar slants were prepared on sterile test tubes. About ten milliliters of TSI agar was dispensed into each of the test tubes, which would trap the gas if produced. The test tubes were autoclaved and inoculated by stabbing the butt and streaking the slant with a loopful of $24 \mathrm{~h}$ old cultures of the test organisms after then incubated for $1-2$ days at $36 \pm 1{ }^{\circ} \mathrm{C}$ and observed for acid and gas production. Yellow coloration indicates acid production, red or pink coloration indicates that it is alkaline while gas production was indicated by cracks and breakage on the medium (modified Fawole and Oso, [12]).

\subsection{Genetic Characterization}

After the morphological and biochemical identification of the isolate, pure culture of the isolate was sent for genetic characterization at Macrogen Inc., The Netherlands to confirm which species/Serova the isolate belongs.

\subsection{MFC Construction and Fabrication}

This was done using the modified methods of Adeleye, and Okorondu; Singh, et al. $([1,41])$.

\subsubsection{Electrode}

Graphite rods was used as the electrode of choice and was purchased from Onitsha main market. The electrodes were cut to the same size and coated with brass mash to increase its surface area thereby encouraging microbial biofilm formation as well as to increase conductivity. The electrodes were soaked in dilute hydrochloric acid $(14.56 \mathrm{ml}$ of $\mathrm{HCl}$ in $985.44 \mathrm{ml}$ of distilled water) for 10 minutes after which they were rinsed in distilled water two times.
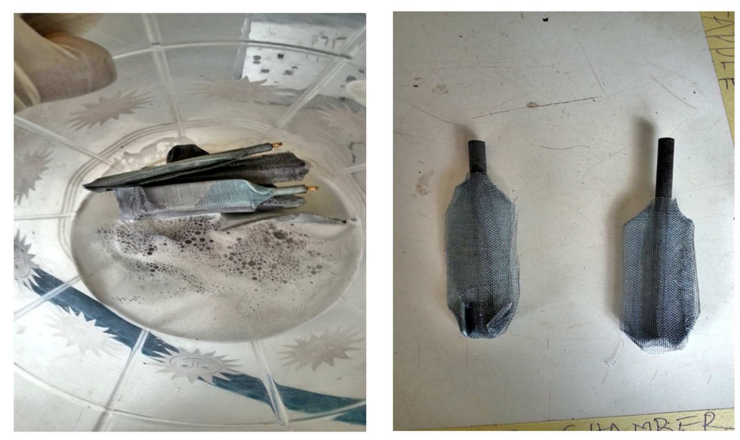

Figure 1. Graphite electrode. 


\subsubsection{Salt Bridge Preparation}

Using modified Adeleye and Okorondu [1] method, a $1 / 2$ inch PVC pipe was cut $8 \mathrm{~cm}$ to make a salt bridge. A $1 / 2$ inch adopter was used to construct a T- junction salt bridge. The PVC pipe was glued to the T- junction using araldite. The salt bridge content was prepared with $2.2 \mathrm{~g}$ of Agar-Agar and $3.75 \mathrm{~g}$ of $\mathrm{NaCl}$ which was dissolved in $50 \mathrm{ml}$ of distilled water. The mixture was heated until a homogenous solution was formed. The two sides of the salt bridge were covered properly with cotton wool before the solution was poured into them. The salt bridges were covered properly with their caps and allowed to gel, after which the cotton wool by the sides was gently removed.

\subsubsection{Constructing the Cathode and Anode Chambers}

About eight (8) 1litre plastics was purchased that served as cathode and anode chambers. Holes of equal diameter to the salt bridge was made $12 \mathrm{~cm}$ from the base of the 1-liter plastic base. The holes drilled serves as a point of attachment for the salt bridge and the two chambers. After the holes were made, they were glued using araldite glue (available in plumbing stores). The gum was mixed with sand and then used to seal the edges of the point of contact between the salt bridges with the chamber to avoid leakages. Next, a hole each was drilled into the lid of the chambers to allow the passage of wire and an extra hole for the cathode chambers which will allow passive aeration of the cathode chambers respectively. The four (4) set-ups produced was allowed to dry and solidify.

\subsubsection{Coupling the Microbial Fuel Cell}

The set-up was coupled with the electrode of choice (graphite and brass mash) by joining them with low resistance wires through the small holes made on the lid of the covers of the chambers. The coupled microbial fuel cells were then sterilized under a laminar flow cabinet having UV light for 1hour.

\subsection{Population Growth Determination by Spectrometric Monitoring}

This was done by using the modified method of Saravanakumari and Angel [39]. It works by measuring the absorption of light by the cells (turbidity) where only strong pigmented cells such as phototrophic bacteria cause a very significant absorption of light in addition to scattering. Nutrient broth was prepared, $0.8 \mathrm{~g}$ in $100 \mathrm{ml}$ of distilled water and sterilized. After cooling, it was dispensed into five different sterilized test tubes. The tubes were later inoculated with a loopful of the stored pure culture (a day old) and labelled in this manner respectively. Optical density at a wave length of $540 \mathrm{~nm}$ was taken 5 times at 2 days interval.

\subsection{Effect of Aeration and Non-aeration in the Cathode chamber of MFC by Multimetric Monitoring}

The already prepared organic wastes was placed into the 1 litre anode compartments respectively as the carbon source with the bioelectrogenic organism of choice and a pinch of
$\mathrm{NaCl}$ was added to aid the flow of ions via the salt bridge. To create an anaerobic condition at the anode compartments, $\mathrm{CaO}$ (quick lime) was added. $\mathrm{KCl}$ was added to the cathode as the catholyte. The lid of the chambers was used to passively aerate the cathode using an air pump as the terminal electron acceptor. The digital multimeter was connected to the cathode and the anode with the aid of the low resistance wire connected to the graphite electrode used in the chambers. Next the multimeter set at $2000 \mathrm{~m}$ for measuring DC current in millivolts and milliamps for current. The initial reading was taken at day 1 and subsequent readings were taken every 24 hours for ten days. Figure 1 shows a schemata and complete microbial fuel cell set up as explained above. The effect of non-aeration was done by covering the cathode compartment of the MFC to prevent air entrance, and the readings were taken using a digital multimeter for the same time interval.

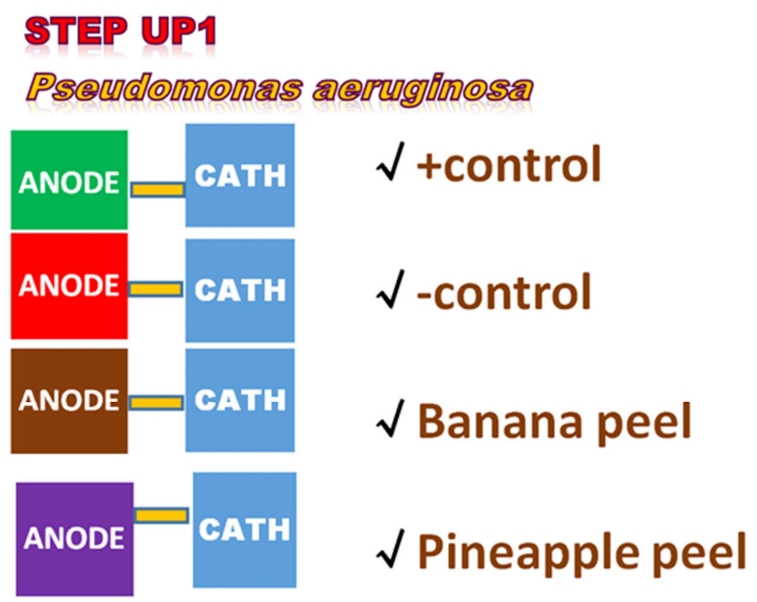

Figure 2. Schematics for the effect of aeration and non-aeration.

\section{Results}

\subsection{Isolation of the Bacterial Isolate}

The isolates were grown on Cetrimide agar and nutrient agar. The media acts as both selective and differential for Pseudomonas aeruginosa family because they contain an inhibitory agent and dye that distinguishes them from other organisms. Careful observation was made from zero hour till when there were visual evidence of growth on the agar plates as shown in table 1, figure 3 and 4 . The morphological characteristics included.

Table 1. Morphological characteristics of isolate.

\begin{tabular}{ll}
\hline Morphology & Characteristics \\
\hline Aerobic growth & $+\mathrm{VE}$ \\
Gram staining & $-\mathrm{VE}$ \\
Colony color & Greenish \\
Colony morphology & Smooth \\
Structure & Rods \\
Motility & Highly motile \\
Spore & Non-Sporing \\
Probable identity & Pseudomonas aeruginosa \\
\hline
\end{tabular}




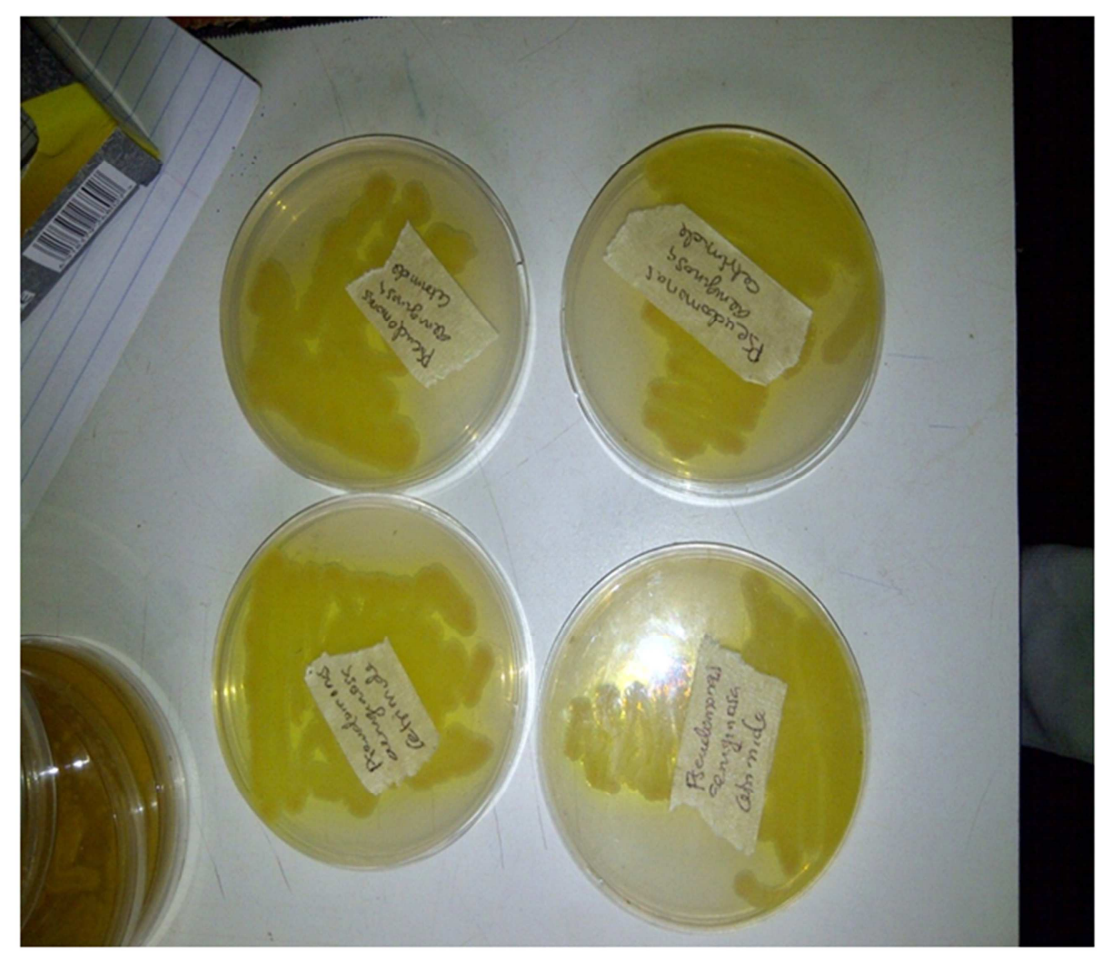

Figure 3. Pseudomonas aeruginosa on cetrimide agar.

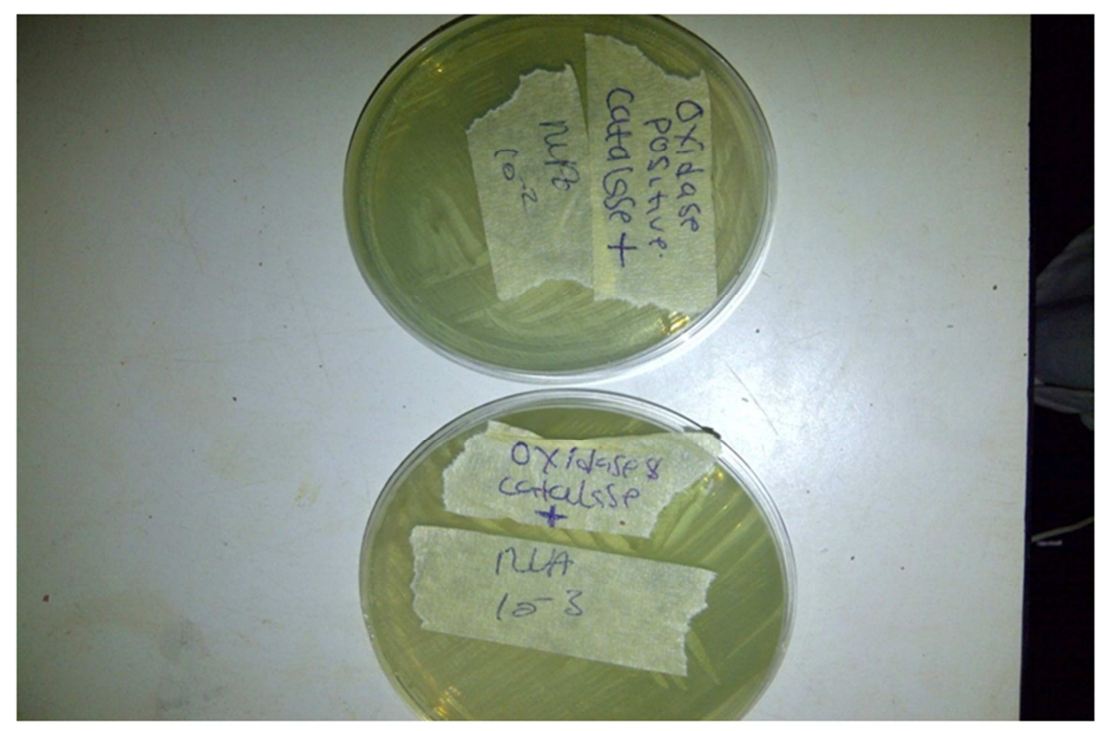

Figure 4. Pseudomonas aeruginosa on nutrient agar.

\subsection{Identification of Bacterial Isolates}

The isolate was tentatively identified macroscopically based on morphology, microscopically and genetically. Various bio-chemical tests were carried out such as gram staining, oxidase test, urease test, catalase test, citrate test, methyl red test, voges-proskaeur test, indole test and sugar fermentation test. The results for the biochemical tests as in Table 2 showed the organism to be oxidase, catalase, citrate positive and urease, indole, methyl red, vogers and $\mathrm{H}_{2} \mathrm{~S}$ negative.
Table 2. Biochemical tests and their result on isolate.

\begin{tabular}{ll}
\hline Biochemical Tests & A \\
\hline Oxidase & $+\mathrm{VE}$ \\
Catalase & $+\mathrm{VE}$ \\
Citrate & $+\mathrm{VE}$ \\
Urease & $-\mathrm{VE}$ \\
Gas & $-\mathrm{VE}$ \\
$\mathrm{H} 2 \mathrm{~S}$ & $-\mathrm{VE}$ \\
Indole & $-\mathrm{VE}$ \\
Methyl red & $-\mathrm{VE}$ \\
Vogers test & $-\mathrm{VE}$ \\
Probable identity & Pseudomonas aeruginosa \\
\hline
\end{tabular}

Key: + VE $=$ Positive, - VE $=$ Negative. 


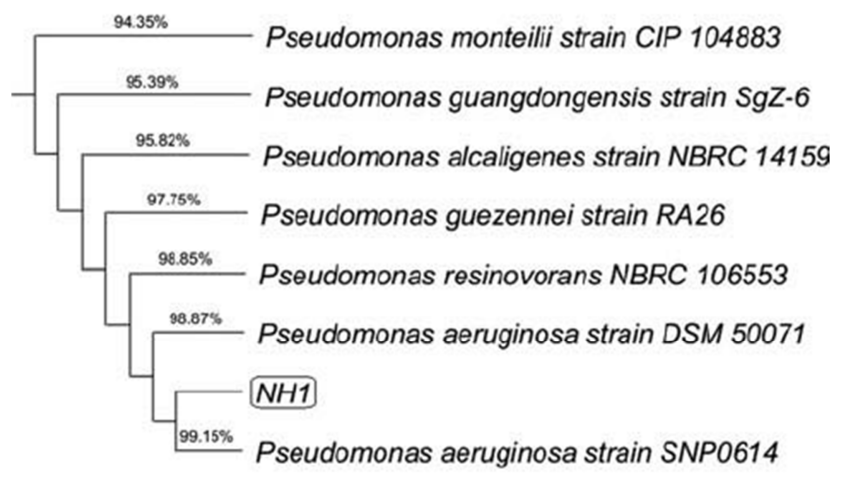

Figure 5. Blast tree for Pseudomonas aeruginosa.

\subsection{Population Growth Determination of Identified Isolates}

The results showed that there was significant growth increase by turbidity and absorbance from day 1 up till day 10 and this can be seen in table 3 below.

Table 3. Population growth determination reading using spectrophotometer at wavelength of $540 \mathrm{~nm}$.

\begin{tabular}{lll}
\hline Day (24 hr.) & Control & A \\
\hline $\begin{array}{l}\text { Day 1 } \\
\text { Absorbance } \\
\text { Day 4 }\end{array}$ & 0.967 & 1.148 \\
$\begin{array}{l}\text { Absorbance } \\
\text { Day 7 }\end{array}$ & 0.967 & 1.572 \\
$\begin{array}{l}\text { Absorbance } \\
\text { Day 10 }\end{array}$ & 0.967 & 1.714 \\
Absorbance & 0.967 & 1.837 \\
\hline
\end{tabular}

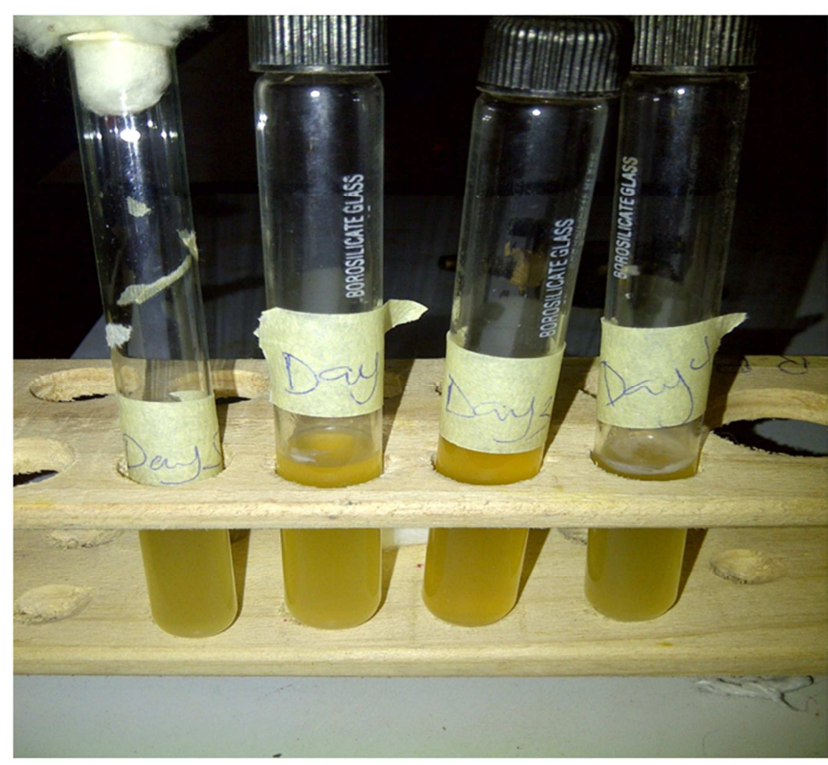

Figure 6. Turbidometric evidence of growth of Pseudomonas aeruginosa on nutrient broth.

\subsection{Effect of Aeration and Non-aeration on Current Generation in the MFC}

Below is the result for the effect of aeration and nonaeration in the MFC, from the results it was noticed that when the chambers were aerated there was significant increase on the voltage produced using a digital multimeter.

KEY: A= Pseudomonas aeruginosa.

Table 4. Power (Watts) produced by aeration.

\begin{tabular}{llll}
\hline DAYS (24hrs interval) & CONTROL & GLUCOSE & BANANA \\
\hline DAY 1 & $6.1620 \times 10^{-6}$ & $3.9825 \times 10^{-4}$ & $7.1625 \times 10^{-4}$ \\
DAY 2 & $5.1830 \times 10^{-6}$ & $1.8901 \times 10^{-6}$ & $3.3988 \times 10^{-4}$ \\
DAY 3 & $4.0300 \times 10^{-6}$ & $8.5932 \times 10^{-5}$ & $1.4964 \times 10^{-4}$ \\
DAY 4 & $1.84500 \times 10^{-6}$ & $4.3520 \times 10^{-5}$ & $6.8670 \times 10^{-5}$ \\
DAY 5 & $8.9900 \times 10^{-7}$ & $2.3407 \times 10^{-5}$ & $4.1475 \times 10^{-5}$ \\
DAY 6 & $4.6800 \times 10^{-7}$ & $9.6600 \times 10^{-6}$ & $1.3746 \times 10^{-5}$ \\
DAY 7 & $1 . .6200 \times 10^{-7}$ & $4.3120 \times 10^{-6}$ & $9.3240 \times 10^{-5}$ \\
DAY 8 & 0 & $1.5810 \times 10^{-6}$ & $3.2760 \times 10^{-5}$ \\
DAY 9 & 0 & $9.5000 \times 10^{-7}$ & $5.0868 \times 10^{-5}$ \\
DAY 10 & 0 & $5.5100 \times 10^{-7}$ & $6.5136 \times 10^{-4}$ \\
DAY 11 & 0 & $1.280 \times 10^{-7}$ & $3.5880 \times 10^{-5}$ \\
\hline
\end{tabular}

Table 5. Power (Watts) produced by non- aeration.

\begin{tabular}{llll}
\hline DAYS (24hrs interval) & CONTROL & GLUCOSE & BANANA \\
\hline DAY 1 & $5.6250 \times 10^{-6}$ & $3.9358 \times 10^{-4}$ & $7.0585 \times 10^{-4}$ \\
DAY 2 & $4.7570 \times 10^{-6}$ & $1.8560 \times 10^{-4}$ & $3.3524 \times 10^{-4}$ \\
DAY 3 & $3.4810 \times 10^{-6}$ & $8.0464 \times 10^{-5}$ & $1.4484 \times 10^{-4}$ \\
DAY 4 & $1.4800 \times 10^{-6}$ & $4.0777 \times 10^{-5}$ & $6.4640 \times 10^{-5}$ \\
DAY 5 & $6.9600 \times 10^{-7}$ & $2.1930 \times 10^{-5}$ & $3.9330 \times 10^{-5}$ \\
DAY 6 & $3.8400 \times 10^{-7}$ & $8.5120 \times 10^{-6}$ & $1.2768 \times 10^{-5}$ \\
DAY 7 & $8.8000 \times 10^{-8}$ & $3.6800 \times 10^{-6}$ & $8.3640 \times 10^{-6}$ \\
DAY 8 & 0 & $1.2740 \times 10^{-6}$ & $3.0622 \times 10^{-5}$ \\
DAY 9 & 0 & $7.0000 \times 10^{-6}$ & $4.8356 \times 10^{-5}$ \\
DAY 10 & 0 & $2.7500 \times 10^{-6}$ & $5.9590 \times 10^{-6}$ \\
DAY 11 & 0 & $9.100 \times 10^{-6}$ & $3.1902 \times 10^{-5}$ \\
\hline
\end{tabular}




\subsection{Statistical Analysis Using Students Test for Aerated and None-Aerated Test}

This is a statistical test in which the test statistics follows a student's T. distribution. It is used to test if two sets of data are significantly different from each other.

Table 6. Statistical representation for aerated and non-aerated chambers.

\begin{tabular}{lll}
\hline Substrates & Aerated chambers (total W output) & Non Aerated chambers (total W output) \\
\hline Glucose & $7.57301 \times 10^{-4}$ & $7.36883 \times 10^{-4}$ \\
Banana & $1.434089 \times 10^{-3}$ & $1.399695 \times 10^{-3}$ \\
Pineapple & $2.402617 \times 10^{-3}$ & $2.344199 \times 10^{-3}$ \\
\hline
\end{tabular}

Paired t Test $=\left(\operatorname{mean}_{1}-\operatorname{mean}_{2}\right) \div$ standard error

Standard error $=$ Standard deviation $\div \sqrt{\mathrm{n}}=1.111 \times 10^{-5}$

$$
\begin{gathered}
\mathrm{n}=3 \\
\text { Standard deviation }=\frac{\sqrt{\left(\sum \text { of deviation }{ }^{2}-\left(\sum \text { deviation }\right)^{2} \div n\right)}}{n-1}=1.924 \times 10^{-5} \\
\text { t Test }=\left(7.4 \times 10^{-9}-4.2710^{-9}\right) \div 1.111 \times 10^{-5}=3.33 \\
\text { Table 7. T test. for aerated and non-aerated chambers. }
\end{gathered}
$$

\begin{tabular}{lll}
\hline T. Test value & Standard error & Degree of freedom \\
\hline 3.33 & $1.111 \times 10^{-5}$ & 2 \\
\hline
\end{tabular}

Critical value $=3.182$

Alternate hypothesis was accepted because the critical value is less than the $t$. Test value and this means that there is significant difference between the two samples.

$$
\mathrm{P}<0.05
$$

\section{Discussion}

Both waste disposal crisis and fossil fuel combustion problems may no longer continue to be challenging occurrences. Since wastes that are regularly generated comprise about $60 \%$ of agricultural wastes, these can be channeled towards bioelectricity production by means of MFCs with suitable biocatalysts as is revealed in this present study, which demonstrated the possible application of different organic wastes for electricity generation using microbial fuel cell technology.

The effect of aeration and non-aeration with Pseudomonas aeruginosa by multimetric monitoring are shown in Tables 4 - 5. Table 4 showed that when addition air was introduced in the cathode end of the MFCs, there was increase in the amount of power and current recorded as compared to when no air were added. The aerated chambers gave maximum power and current of $8.99 \times 10-4 \mathrm{~W}$ and $998 \mathrm{~mA}$ at day 1 of the operation when pineapple peel was used as electron donor, see table 4. As earlier stated, time was also a good factor to be considered. As time increased, there was always a fall in the amount of power produced. This was as a result of a reduction in the available nutrients and carbon sources present in the substrates as well as the growth pattern of each organism. This is because the organisms tend to reduce in the work output as they head toward the stage of decline $\backslash$ death. See tables $4-5$. Previous studies carried out on the effect of aeration and non-aeration by some scientists like Booki et al. [3], proposed and analysed the exoelectrogenic ability of Pseudomonas aeruginosa and discovered its high exoelectrogenic content and approved it as a very good organism for the driving of a microbial fuel while using glucose as a substrate. The study followed the same trend reported above by Booki et al. [3] but using additional two substrates which included pineapple waste and banana peel. The samples used for the isolation of Pseudomonas aeruginosa were gotten from waste water from dustbins and soil all in Uli and was isolated on both nutrient and cetrimide agar which yielded pigmented colonies as a result of phenazine and pyocyacin production by the organisms. See figure 3 and 4 respectively. This shows that this organism Pseudomonas aeruginosa is also native of Uli, and the one isolated from here was also proven to be a very good organism with endoelectrogenic property which made it useful and essential in the running of microbial fuel cells. It is also economical as it cuts out the expenses imposed by the use of artificial mediator which act as electron shuttle by producing its own as proposed by Derek [8]. The inoculation of the organism into the different anode chambers in the MFCs was done at a $\mathrm{pH}$ of near neutrality $(7.2-7.6)$ and the different chambers yielded different ampere of currents and volts of voltage which was as a result of the amount of carbon supplied by the substrates and internal resistance. The different statistical tools (T. test) employed indicated that there was significant difference between the aerated and nonaerated chambers because the critical value is less than the test value. So therefore, the Alternate hypothesis should be accepted $(\mathrm{P}<0.05)$.

In the MFCs, the electricity was produced by the microbial 
growth in the anaerobic anode compartment, while the organic wastes (substrates) were consumed by active microorganisms or enzymes. Four (4) double chambered microbial fuel cells (MFC) were fabricated and graphite rods were used as electrodes and inoculated with pure culture of Pseudomonas aeruginosa. The electrodes were wrapped with wire gauze to increase its surface area for bacterial attachment and boost increase in voltage. It was tightly fixed with the containers containing medium, culture and a buffer which is in accordance with Wei et al. [43].

Table 3 shows an absorbance recorded by the aid of a spectrophotometer at $540 \mathrm{~nm}$ for population growth determination of isolates to be used for the investigations. At the beginning of the experiment, absorbance was less than 1.148 and gradually increased as 1.572, 1.714, 1.837 respectively for each day interval. The result clearly showed what happens during the growth stages of microorganisms, where at the beginning of growth, the organisms are adapting to their new environment but as time goes on there is exponential increase in the microbial population size. The investigation was carried out using modified method of Saravanakumari and Angel [39].

The bacterial isolates used for these studies were identified based on cultural, microscopic (table 1) and genetic characteristics. Various biochemical tests were carried out such as oxidase test, catalase test, indole, urease, methyl red test and vogers test (table 2).

Table 1 showed that the bacterial isolate was aerobic, Gram-negative, motile rods, non-sporing greenish on nutrient plates. The biochemical tests by Bergys criteria revealed the isolates as belonging to the Pseudomonas spp., but further characterization genetically showed the bacterial isolates to be Pseudomonas aeruginosa.

The results from these investigations showed that Pseudomonas aeruginosa can be used as electrogen for bioelectricity generation in an MFC and the organic wastes pineapple peel, and banana peel were able to support their growth and as such, they should not be seen as a mere waste.

\section{Conclusion}

This study revealed that the microbial fuel cells fabricated has good ability to be used to house the substrates and organisms in an anaerobic environment for electricity generation. Fermentation of the three different substrates such as glucose, banana peel and pineapple peel for power production was successfully carried out in the duel chamber of the fabricated MFCs. An interesting point was that sources of electron donors have important role in the efficiency of the microbial fuel cells. Results obtained showed that the eight (4) chambers MFC successfully produced bioelectricity from different kinds of organic wastes without using any mediator in the anode compartments. The maximum current and power obtained for the effect of aeration/non-aeration were $1.17 \mathrm{X}$ 10-3 A, 8.99 X 10-4W and 998mA respectively.

The electricity supply in the $H$ shape microbial fuel cell was unstable. Therefore, more research is needed to combat the internal resistance and produce better electrodes and devices that will trap the electricity for large scale purposes.

\section{Recommendation}

Indeed, the real potential of MFCs in electricity generation has not been fully harnessed in developing countries. Therefore, it is recommended that technological development in this area be enhanced to boost commercialization of microbial fuel cells.

\section{References}

[1] Adeleye, S. A. and Okorondu, S. I. (2015). Bioelectricity from students' hostel waste water using microbial fuel cell. International Journal of Biological and Chemical Science 9(2): $1038-1049$.

[2] Bond, D. R. and Lovley, D. R. (2003). Electricity production by Geobacter sulfurreducens attached to electrodes. Applied and Environmental Microbiology 69: 1548-1555.

[3] Booki, M., Shaon-cheng and Bruce, E. (2005). Electricity generation using Membrane and Salt bridge microbial fuel cells. Journal of Water Research1675-1686.

[4] Bruce, E. and Logan, B. E. (2009). Exoelectrogenic bacteria that power microbial fuel cell. Trends Microbiology 375-381.

[5] Chaudhuri, S. K. and Lovley, D. R. (2003). Electricity generation by direct oxidation of glucose in mediatorless microbial fuel cells. Nature Biotechnology 21: 1229-1232.

[6] Cheesbrough, M. (2006). District laboratory practice in tropical countries. 2nd Edn. Cambridge University Press, Cambridge, UK., ISBN-13: 9781139449298.

[7] Cohen, B. (1931). The Bacterial Culture as an Electrical HalfCell. Thirty-second Annual Meeting of the Society of American Bacteriologists.

[8] Derek R. L. (2008). The Microbe electric: Conversion of organic matter to electricity. Current Opinion in Biotechnology19: 564-571.

[9] Di-yan. (2014). Electricity generation and H2 evolution by microbial fuel cell. Journal of Environmental Sciences110 135 .

[10] Du, Z., Li, H. and Gu, T. (2007). A State of the Art review on microbial fuel cells: A promising technology for wastewater treatment and bioenergy. Biotechnology Advances25: 464-482.

[11] Fan, Y., Sharbrough, E. and Liu, H. (2008). Quantification of the internal resistance distribution of microbial fuel cells. Environmental Science \& Technology42: 8101-8107.

[12] Fawole, M. O. and B. A. Oso, (2004). Characterization of Bacteria: Laboratory Manual of Microbiology. 4th Edn., Spectrum Book Ltd., Ibadan, Nigeria, pp: 24-33.

[13] Ghangrekar, M. M. and Shinde, V. B. (2006). Wastewater Treatment in Microbial Fuel Cell and Electricity Generation: A Sustainable Approach. Paper presented in the 12th international sustainable development research conference. Hong Kong, April 6-8. 
[14] Ghoreyshi, A., Jafary, T., Najafpour, G. D. and Haghparast, F. (2011). Effect of type and concentration of substrate on power generation in a dual chambered microbial fuel cell. Journal of World Renewable Congress 1175-1181.

[15] Gil, G. C., Chang, I. S., Kim, B. H., Kim, M., Jang, J. Y., Park, H. S. and Kim, H. J. (2003). Operational parameters affecting the performance of a mediatorless microbial fuel cell. Biosensensor and Bioelectronics 18: 327-334.

[16] Huang, L., Regan, J. M. and Quan, X. (2011). Electron transfer mechanisms, new applications, and performance of biocathode microbial fuel cells. Bioresource Technology, 10: 316-323.

[17] Ieropoulos, I., Melhuish, C. and Greenman, J. (2003). Artificial metabolism: towards true energetic autonomy in artificial life. Lecture Notes in Computer Science 2801: 792-799.

[18] Ismail, M. and Phadke, R. P. (2014). A PDMS fabricated miniature microbial fuel cell. International Journal of Scientific and Technology Research200-203.

[19] Jang, J. K., Hai, P., Chang, I. S., Kang, K. H., Moon, H., Cho, K. S. and Kima, B. H. (2004) Construction and operation of a novel mediator- and membrane-less microbial fuel cell. Process Biochemistry39: 1007-1012

[20] Jothinathan, D., Sundaram, M. and Wilson, R. (2013). A study of bioelectricity production by the synergistic action of Bacillus tequilensis and Pseudomonas aeruginosa isolated from rumen fluid. American Journal of Environmental Sciences9: 424-430.

[21] Kim, H. J., Park, H. S., Hyun, M. S., Chang, I. S, Kim, M. and Kim, B. H. (2002). A mediatorless microbial fuel cell using a metal reducing Bacterium, Shewanella putrefaciens. Enzyme and Microbial Technology 30: 14-152.

[22] Kun, Daniel, J., Hassell and Tingyue, J. (2012). Microbial fuel cell: Electricity generation from organic waste by microbes. In R. Arora (Ed.) Microbial Biotechnology: Energy and environment. (Pp. 162-189). United Kingdom: CAB International, Oxon press.

[23] Logan, B. E. (2006). Electricity-Producing bacterial communities in microbial fuel cells. Trends in Microbiology 14: $512-518$.

[24] McKellar, R. and Lu, X. (2004). Modeling Microbial Responses on Foods. CRC Press: Boca Raton, FL.

[25] Min, B., Kim, J. R., Oh, S. E., Regan, J. M. and Logan, B. E. (2005). Electricity generation from swine wastewater using microbial fuel cells. Water Research 3: 4961 - 4968.

[26] Mokhatarian, Rshimnejad, M. G. D., Najafpour and Ghoreyshi, B. (2012). Effect of different substrate on performance of microbial fuel cell. African Journal of Biotechnology3363 - 3369 .

[27] Moon, H., Chang, I. S. and Kim, B. H. (2006). Continuous Electricity production from artificial wastewater using a Mediator-less Microbial Fuel Cell. Bioresource Technology 97: 621-627.

[28] Nelli and Beecroft. (2010). Development of microbial community Dynamics. American Journal of Environmental Science201-263.

[29] Olutiola, P. O., Famurewa, O. and Sonntag, H. G. (2000). Introduction to General Microbiology: A Practical Approach. 2nd Edn., Bolabay Publications, Ikeja, Nigeria.

[30] Park, D. H. and Zeikus, J. G. (2003). Improved fuel cell and electrode designs for producing electricity from microbial degradation. Biotechnology and Bioengineering 81: 348-355.

[31] Peleg, M. (2006). Advanced Quantitative Microbiology for Food and Biosystems: Grades of Graphite. Journal of Green Engineering4: 13-32.

[32] Pranab, K. and Deka, D. (2010). Electricity generation from bio waste based microbial fuel cells. International Journal of Energy, Information and Communications 77-92.

[33] Potter, M. C. (1911). Electrical Effects Accompanying the Decomposition of Organic Compounds. Royal Society of London 84(571): 260-276.

[34] Rabaey, K. and Verstraete, W. (2005). Microbial fuel cells: Novel Biotechnology for energy generation. Trends Biotechnology23: 291-298.

[35] Rakesh, Chandra, Ujwal, S. M. and Suresh, R. (2014). Performance Studies on Microbial fuel cell. International Journal of Research in Engineering and Technology169-173.

[36] Reddy, N., Nirmal R. K., Ajay, B. O. and Muralidharan, K. (2007). A Potential stage in wastewater treatment for generation of bioelectricity using MFC. Current Research Topics in Applied Microbiology and Microbial Biotechnology 1: 322326 .

[37] Rozendal, R., Hamelers, H. V., Rabaey, K., Keller, J. and Buisman, C. J. (2008). Towards practical implementation of bioelectrochemical wastewater treatment. Trends in Biotechnology 26: 450-459.

[38] Saravanakumari, P. and Angel, D. (2015). Two chamber microbial fuel cells for electricity generation using different carbon sources. British Microbiology Research Journal 5(1): $12-21$.

[39] Shafiee, S. and Topal, E. (2009). When will fossil fuel reserves be diminished? Energy Policy 37: 181-189.

[40] Singh, D., Pratap, Y., Baranwal, B., Kumar and Chauddhary, R. K. (2010). Microbial fuel cells: A Green technology for power generation. Annals of Biological Research128-138.

[41] Wang, X., Feng, Y., Z. and Hao, Q. (2009). Accelerated startup of two chambered microbial fuel cells; effect of positive poised potential. Journal of Electrochemical Activity54:11091114.

[42] Wei, J., Liang, P. and Huang, X., (2011). Recent progress in electrodes for microbial fuel cells. Bioresources Technology11:1-47.

[43] Yongtae A, Marta, C. Hatzell F. Z., and Logan B. E. (2014). Different electrode configurations to optimize performance of multielectrode microbial fuel cells for generating power or treating domestic wastewater. Journal of Power Sources249: $440-445$. 